\title{
JENIS TUMBUHAN YANG DIMANFAATKAN SEBAGAI SUMBER PANGAN OLEH MASYARAKAT DESA JAWAI LAUT KECAMATAN JAWAI SELATAN KABUPATEN SAMBAS
}

\author{
(Species Of Plants Used As Food Sources By The Communities Of The Jawai Laut Village, \\ Jawai Selatan District, Sambas Regency)
}

\author{
Liza, H. A. Oramahi, Lolyta Sisillia \\ Fakultas Kehutanan Universitas Tanjungpura Jl. Daya Nasional, Pontianak 78124 \\ E-mail : izaliza049@gmail.com
}

\begin{abstract}
The plant's species which used as a food source by humans that contains carbohydrates and can produce energy as a source of protein, vitamins, fats, and minerals. The purposes of this research were to obtain the data of the species of plants used as food sources and also to obtain data on the plant parts and how to process these plants as food sources used in Jawai Laut Village, South Jawai District, Sambas Regency. The data is collected by using a survey method through semistructured interviews with the respondents using a purposive sampling technique. The results of the research found that 58 species of plants belonging to 30 families. Most of them are in the family of Arecaceae, Solanaceae, Moraceae 4 species. The part used is the fruit of 40 species (56\%). The plants used as vegetables, spices, and beverage ingredients. There are 28 species (41\%) of plants which used by direct consumption, 35 species (51\%) of cooked plants, 3 species (4\%) of mashed plants, 3 species (4\%) of mined plants, and most of the plants which used are from the fruit group, there are 34 species (59\%), 12 species of vegetables (21\%). Food plants are obtained from the cultivation of 48 species (79\%), and wild plants 19 species (30\%).
\end{abstract}

Keyword: Food sources, Jawai Laut Village, Plant species

\section{PENDAHULUAN}

Hutan sebagai suatu ekosistem yang tidak hanya menyimpan sumberdaya alam berupa kayu, tetapi masih banyak potensi hasil hutan bukan kayu (HHBK) yang dapat diambil manfaatnya, salah satu adalah tumbuhan sebagai sumber pangan yang biasa dimanfaatkan oleh masyarakat untuk memenuhi kebutuhan pangan sehari-hari (Sumarlin et al. 2015). Jenis tumbuhan yang sering dijadikan sebagai bahan pangan oleh manusia berupa tumbuhan yang memiliki kandungan karbohidrat melimpah dan jenis tumbuhan lain yang dapat menghasilkan energi. Bagian bagian tumbuhan yang dapat dimanfaatkan pun beragam, mulai dari akar, batang, daun, bunga, biji, hingga buahnya, tumbuhan pun dapat dimanfaatkan manusia dalam berbagai aspek kehidupan (Sisilahi et al. 2018).

Kebutuhan pangan adalah kebutuhan yang paling utama bagi manusia. Kebutuhan pangan terus meningkat karena peningkatan jumlah penduduk, pemenuhan kebutuhan pangan seharusnya dapat dilakukan dengan memanfaatkan sumber daya alam yang berpotensi disekitar kita. Wilayah Desa Jawai Laut Kecamatan Jawai Selatan Kabupaten Sambas terdapat tiga dusun yaitu Dusun Bukit Raya, Dusun Ramayadi, Dusun Kalang 
bahu. Masyarakat sekitar desa jawai laut telah memanfaatkan tumbuhan sebagai sumber bahan pangan untuk kebutuhan sehari-hari yang telah dilakukan secara turun-temurun. Masyarakat setempat bekerja sebagai petani dan nelayan untuk memenuhi kebutuhan mereka sehari hari. Di desa Jawai Laut belum ada penelitian tentang tumbuhan sumber pangan untuk itu perlu dilakukan penelitian tentang tumbuhan yang dimanfaatkan oleh masyarakat sebagai sumber pangan di Desa Jawai Laut Kecamatan Jawai Selatan Kabupaten Sambas.

Berdasarkan hasil penelitian Setiawan dan Qiptiyah, (2014) menemukan 68 jenis tumbuhan sumber pangan yang dimanfaatkan oleh masyarakat adat Suku Mororene, tumbuhan tersebut didapat berasal dari hutan yang dijadikan sumber pangan pengganti makanan pokok yaitu Aren (Arenga pinnata), Ondo (Diosccorea hispida), garut (Marantha arunginaceae), Talas (Colacasia esulenta), dan Rumbia (Metroxylon sago). Berdasarkan hasil penelitian Irsyad et al. (2013) ditemukan 90 jenis tumbuhan bahan pangan, bahan pangan dibedakan sebagai bahan pangan pokok yaitu padi (Oryza sativa) dan bahan pangan tambahan yaitu terong (Solanum melongena), singkong (Manihot utilissima.), cabe (Capsicum fruetescent), secang (Caesalpinnia sappan), alang-alang (Imperata cylindrica), jahe (Zingiber officinale), sereh (Cymbopogon nardus), kencur (Kaempferia galanga), temulawak
(Curcuma xanthorhiza). Perbedaan jumlah jenis tumbuhan dipengaruhi oleh daerah tumbuh (Romana et al. 2015).

Tujuan dari penelitian ini adalah mendata jenis-jenis tumbuhan yang dimanfaatkan sebagai sumber pangan Desa Jawai Laut Kecamatan Jawai Selatan Kabupaten Sambas dan mendapatkan data bagian-bagian tumbuhan dan cara pengolahan tumbuhan tersebut sebagai sumber pangan yang dimanfaatkan oleh masyarakat Desa Jawai Laut Kecamatan Jawai Selatan Kabupaten Sambas dan manfaatnya diharapkan dapat memberikan informasi mengenai tumbuhan sebagai sumber pangan yang dimanfaatkan oleh masyarakat yang ada di sekitar Desa Jawai Laut Kecamatan Jawai Selatan Kabupaten Sambas dan pemanfaatan tumbuhan sumber pangan di masa datang.

\section{METODE PENELITIAN}

Penelitian ini dilaksanakan di Desa Jawai Laut Kecamatan Jawai Selatan Kabupaten Sambas. Waktu penelitian dilakukan selama 2 minggu. Alat dan bahan yaitu peta lokasi, Buku Tumbuhan Berguna (K.Heyne,1987), daftar pertanyaan, tally sheet. Objek penelitian ini adalah masyarakat yang memanfaatkan tumbuhan sebagai sumber pangan di Desa Jawai Laut Kecamatan Jawai Selatan Kabupaten Sambas. Metode yang digunakan dalam penelitian ini adalah Metode survei melalui wawancara semi terstruktur terhadap responden, pemilihan responden menggunakan teknik purposive sampling. Pengambilan 
sampel dalam penelitian ini dilakukan secara purposive sampling, yaitu pengambilan sampel dengan cara sengaja berdasarkan kriteria tertentu. Penentuan jumlah sampel responden menggunakan rumus slovin dengan persen kelonggaran $10 \%$ dengan tingkat kepercayaan $90 \%$ berdasarkan jumlah KK per dusun di Desa Jawai Laut Kecamatan Jawai Selatan Kabupaten Sambas. Perhitungan dilakukan dengan menggunakan Rumus slovin sebagai berikut:

$\mathrm{n}=\frac{N}{1+N e^{2}}$

$\mathrm{n}=$ Ukuran sampel/ jumlah responden

$\mathrm{N}=$ Ukuran populasi

$\mathrm{e}=$ Error (persen kelonggaran)

Berdasarkan perhitungn dengan menggunakan rumus slovin maka diperoleh jumlah responden sebanyak 88 KK dari 766 KK yang ada.

Metode Pengumpulan Data

Data yang dikumpulkan dalam penelitian ini adalah data primer dan data sekunder. Data primer merupakan data yang diperoleh dari hasil wawancara terhadap responden dan pengamatan langsung terhadap tumbuhan sumber pangan yang meliputi : (1) Nama jenis (nama lokal maupun nama ilmiah) untuk jenis tumbuhan sumber pangan (2) Ciri spesifik dari jenis tumbuhan sumber pangan (3) Bagian tumbuhan yang digunakan sebagai sumber pangan (4) Habitat, habitus dan penyebarannya.

Analisis Data

Metode analisis data yang digunakan adalah analisis deskriftif kualitatif. Data hasil wawancara dan pengamataan tumbuhan sumber pangan dianalisis sehingga diperoleh hasil berupa gambaran atau lukisan secara sistematis dan alamat yang meliputi jenis tumbuhan, famili, bagian yang digunakan, cara pengolahan dan manfaat lainnya.

\section{HASIL DAN PEMBAHASAN}

Hasil informasi yang didapat tentang tumbuhan sebagai sumber pangan yang dimanfaatkan oleh masyarakat di Desa Jawai Laut Kecamatan Jawai Selatan Kabupaten Sambas yaitu sebanyak 58 jenis dan terdapat 30 famili tumbuhan yang dimanfaatkan sebagai sumber pangan. Famili dengan spesies terbanyak ditemukan adalah Arecaceae, Solanaceae, Moraceae 4 spesies. Jenisjenis tumbuhan dapat dilihat pada lampiran 1.

Masyarakat Desa Jawai Laut Kecamatan jawai Selatan Kabupaten Sambas memanfaatkan tumbuhan pangan tersebut sebagai makanan pokok, sayur-sayuran, dan makanan ringan (makanan untuk menghilangkan rasa lapar sementara waktu atau memberikan sedikit pasokan tenaga ke tubuh), bumbu masakan, bahan minuman. Bagian tumbuhan yang sering dimanfaatkan sebagai pangan adalah buah sebanyak spesies $56 \%$ (40 spesies). Bagian tumbuhan lain yang sering dimanfaatkan adalah daun $17 \%$ (12 spesies), bunga 4\%(3 spesies), biji 7\% (5 spesies) dan yang paling sedikit adalah tunas muda, umbi, umbut, kulit, akar masing-masing 1 spesies. 


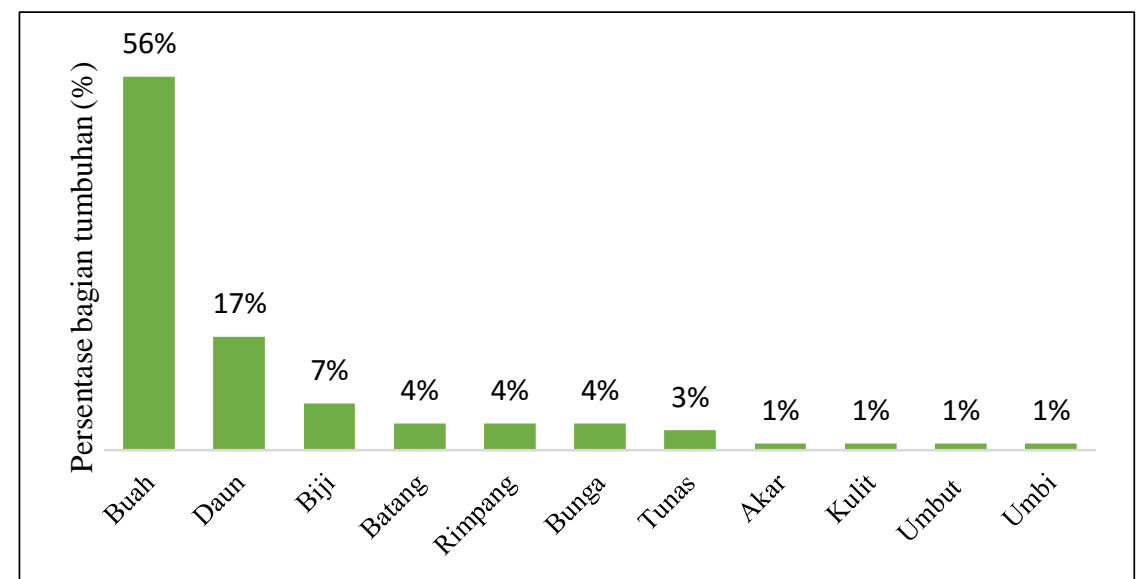

Gambar 1. Bagian Tumbuhan Yang Digunakan Sebagai Pangan (Plant parts used as food)

Makanan pokok penduduk di Desa Jawai laut adalah padi yang dihasilkan dari bercocok tanaman di sawah. Tumbuhan pangan yang dmanfaatkan sebagian besar merupakan makanan pelengkap seperti sayuran dan buahbuahan, bumbu masakan, bahan minuman. Tumbuhan pangan di Desa Jawai Laut yang dimanfaatkan oleh masyarakat sebagai sayur-mayur diantaranya batek/pepaya (Carica papaya L.), midding (Stenochlaena palustris (Burm. Fil) Bedd., kelapak (Cocos nucifera L.), melinjo (Gnetum gnemon), tarrong kokak (Solanum torvum), tarrong asam (Solanum ferox), ulap (Baccaurea motleyana), singkel (Premna foetida) dan sebagainya. Biasanya bagian tumbuhan yang dimanfaatkan sebagai sayuran adalah daun muda yang kemudian dimasak menjadi sayur matang atau mentah sebagai lalapan. Namun ada juga bagian tumbuhan lain yang dimanfaatkan sebagai sayuran misalnya temmadak (Artocarpus champeden), nangkak (Artocarpus heterophyllum) yang diambil buah mudanya untuk dijadikan sebagai lauk sayur. Tumbuhan yang dimanfaatkan sebagai bumbu masakan diantaranya gerinnang (Averrhoa bilimbi), daun kesum (Polygonum minus Huds.), kunyik (Curcuma dosmetica L), lade (Piper nigrum), kalimbawan (Sarcotheca diversifolia), layak (Zingiber officinale) dan sebagainya, sedangkan sebagai bahan minuman yaitu kopi (Coffea sp), tabbu (Saccharum officinarum). Pemanfaatan tumbuhan sebagai sumber bahan pangan dirasakan masyarakat merupakan cara yang paling efektif untuk memenuhi kebutuhan pangan karena biaya yang murah dan mudah diperoleh dilingkungan sekitar. 

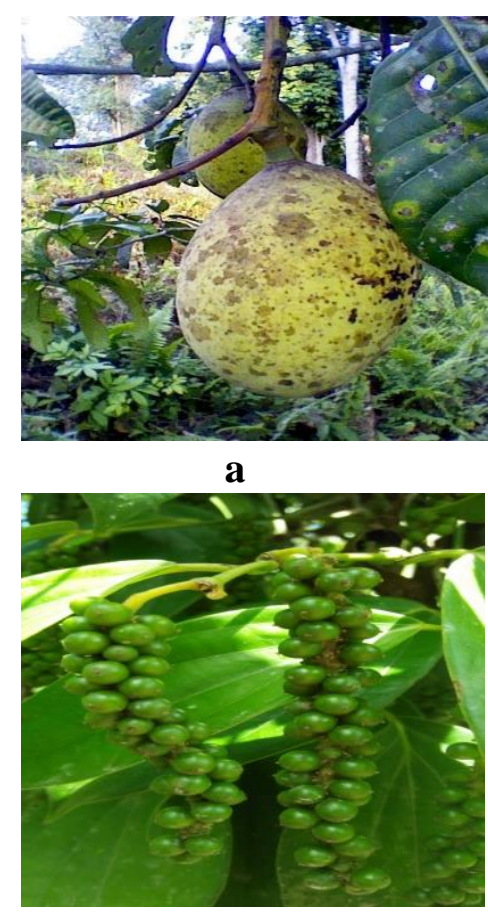

d

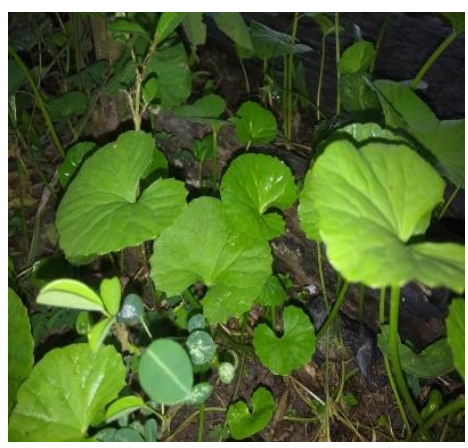

b

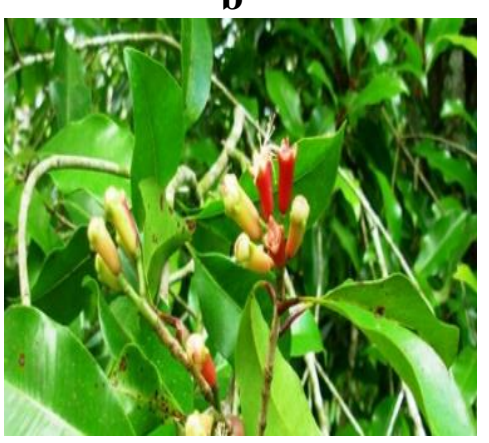

e

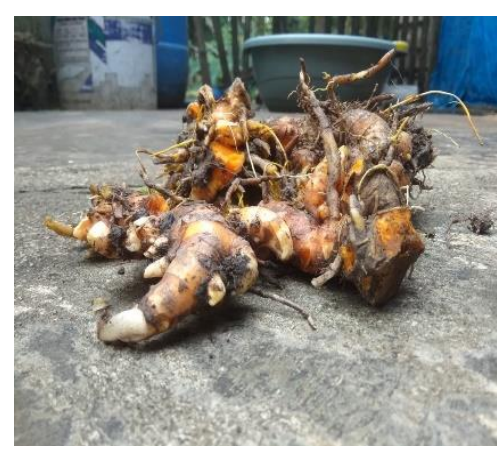

c

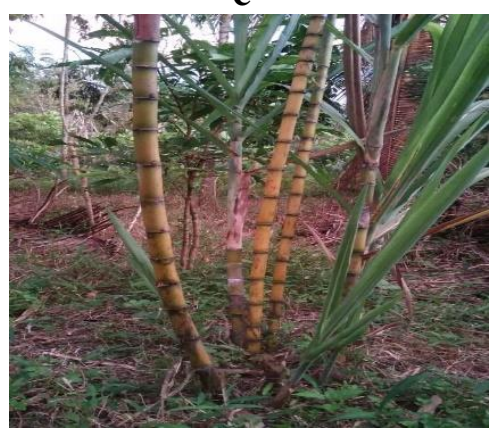

f

Gambar 2. (a). Buah (Fruit) (b). Daun (Leaf) (c). Rimpang (Rhizome) (d). Biji (Seed) (e). Bunga (Flower) (f). Batang (Stem)

Berdasarkan hasil penelitian Juliana et al. (2013), bagian tumbuhan yang paling banyak dimanfaatkan oleh masyarakat di sekitar kawasan Gunung Peramas yaitu buah sebanyak (53\%) diantaranya cempedak (Artocarpus champeden), nangka (Artocarpus. heterophyllum), langsat (Lansium domesticum, Durian (Durio zibethinus), tampoi (Baccaurea macrocarpa), asam bacang (Mangifera foetida), sayuran yaitu pakis merah (Stenochlaena palustris, ubi kayu (Manihot utilissima), bambu betung (Dendrocalamus asper), cangkok manis (Sauropus androgymus) nangka (Artocarpus heterophyllum). Buah-buah yang paling banyak dimanfaatkan karena memiliki daging buah yang umumnya dapat dikonsumsi secara langsung. Dapat dilihat yang sering dimanfaatkan sebagai sumber pangan adalah buah-buahan karena buah-buahan mengandung air yang dapat menghilangkan rasa haus dan lapar pada waktu masyarakat melakukan aktifitas.

Berdasarkan hasil penelitian cara pengolahan yang dijadikan makanan. yaitu dikonsumsi langsung 41\% (28 spesies), dimasak $51 \%$ (35 spesies), dihaluskan $4 \% \quad$ (3 spesies), difermentasikan 4\% (3 spesies) seperti Durian buahnya yang sudah masak bisa dikonsumsi langsung dan dapat dibuat tempoyak, Rambai buahnya yang sudah masak itu juga bisa dikonsumsi langsung dan dapat pula dibuat cuka untuk bahan penambah makanan, sedangkan bagian kulit buah dapat dibuat sayur. Pengolahan tumbuhan sumber pangan 
yang secara sederhana seperti dengan cara dikonsumsi langsung (tanpa diolah), dimasak, dihaluskan, dipermentasikan yang berkaitan dengan pengetahuan masyarakat yang pada umumnya diperoleh secara turuntemurun yang berdasarkan kebiasaan serta pada pengalaman mereka kehidupan sehari-hari. Dilihat dari cara pengolahan tumbuhan sumber pangan yang terbanyak adalah dengan cara dimasak yaitu $51 \%$ (35 spesies) karena dengan cara dimasak makanan tersebut baru bisa dikonsumsi, sedangkan cara pemakaiannya dimakan, ditambahkan dalam masakan dan dijadikan minuman. Cara pemakaian dengan cara dimakan yaitu dapat dikonsumsi langsung atau terlebih dahulu dimasak, dengan cara ditambahkan kedalam masakan yaitu sebagai bumbu masakan untuk mendapatkan cita rasa pada makanan tersebut.

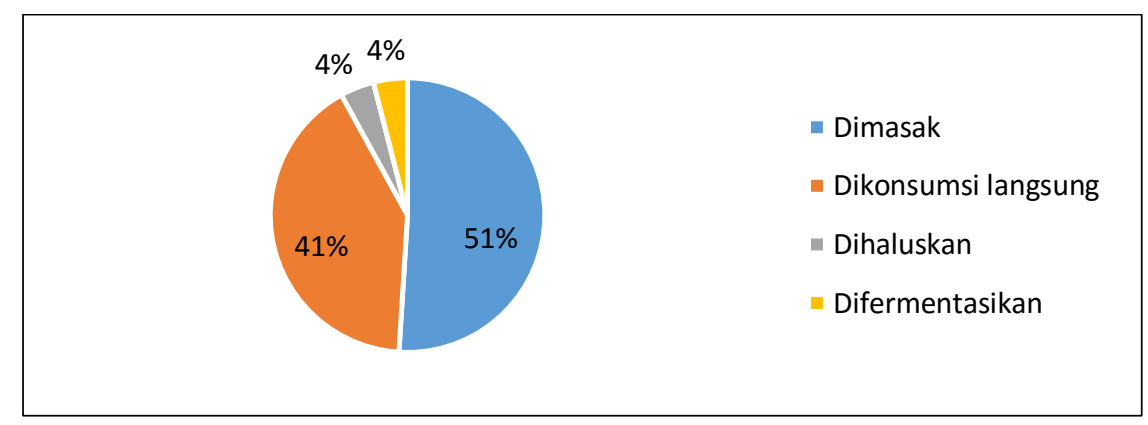

\section{Gambar 3. Cara Pengolahan Tumbuhan Sumber Pangan (How to process food source plants)}

Berdasarkan hasil penelitian Nurchayati dan Ardiansyah (2019), cara pengolahan dan pemakaian tanaman pangan pada masyarakat Suku Using Kabupaten Banyuwangi. Cara pengolahan dilakukan dengan cara direbus, dimasak, tanpa pengolahan (langsung dikonsumsi), dan dihaluskan dan cara pemakaian tanaman pangan oleh masyarakat Suku Using di Kabupaten Banyuwangi diketahui turuntemurun dari generasi pendahulu dikategorikan atas tiga cara yaitu dimakan, ditambahkan dalam masakan dan dijadikan minuman.

\section{Habitat, Habitus, Status Tumbuhan Sumber Pangan}

Berdasarkan habitus tumbuhan sumber pangan yang digunakan dan ditemukan 58 jenis yaitu tingkat pohon, liana, perdu, herba, terna dan semak. Tingkat habitus tumbuhan sumber pangan bahwa habitus yang banyak adalah dari tingkat pohon sebanyak 50\% (29 spesies), tingkat perdu 26\% (15 spesies), herba 19\% (11 spesies), liana, terna dan semak masing-masing $2 \%$ (1 spesies). 


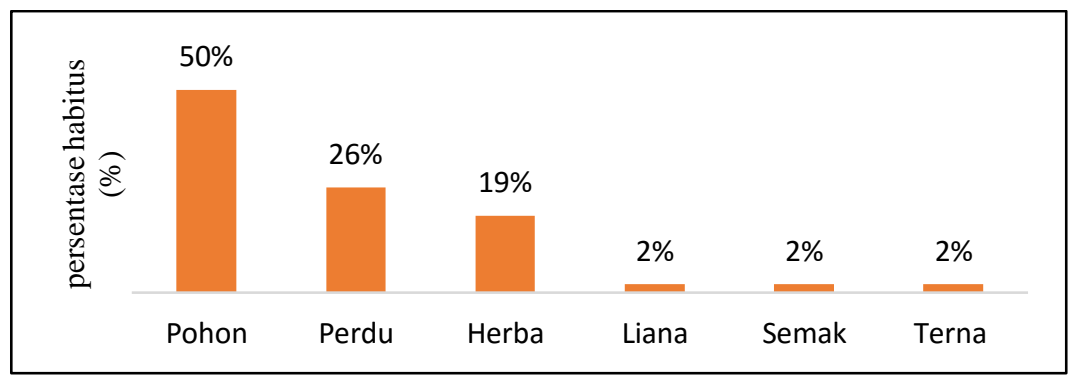

Gambar 4. Habitus Tumbuhan Sumber Pangan

(Food source plant habitus)

Hal ini sejalan dengan penelitian yang telah dilakukan Prabaningrum et al. (2018) di kawasan Cagar Alam Gebungan Semarang bahwa habitus tumbuhan pangan yang paling dominan adalah pohon.

Berdasarkan habitat tumbuhan sumber pangan yang dimanfaatkan oleh masyarakat Desa Jawai Laut Kecamatan Jawai Selatan Kabupaten Sambas terdapat dibeberapa tempat ditemukannya tumbuhan tersebut yaitu ada dihutan $25 \%$ (18 spesies), dikebun $21 \%$ (15 spesies), perkarangan rumah
47\% (34 spesies), disawah $3 \% \quad$ (2 spesies) dan ditepi sungai 3\% (2 spesies). Berdasarkan hasil penelitian yang paling banyak tumbuhan sumber pangan ditemukan adalah di perkarangan rumah. Mulyana (2011), perkarangan merupakan semacam benteng menghadapi ketidakpastian perubahan iklim. Hal ini dimengerti karena didalam perkarangan banyak terdapat tanaman yang dapat dimanfaatkan meskipun tanaman yang diusahakan disawah mengalami kegagalan.

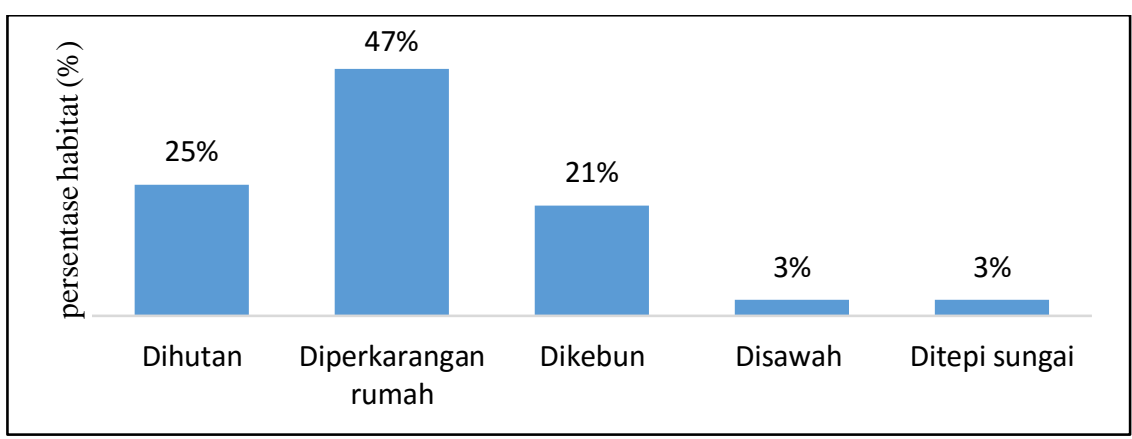

Gambar 5. Habitat Tumbuhan Sumber Pangan (Food source plant habitat)

Berdasarkan status tumbuhan sumber pangan yang dimanfaatkan oleh masyarakat Desa Jawai Laut Kecamatan Jawai Selatan Kabupaten Sambas didapat $70 \%$ (45 spesies) tumbuhan yang dibudidayakan, sedangkan yang tidak dibudidayakan atau tumbuhan liar sebanyak 30\% (19 spesies) dapat dilihat pada gambar 10. Status tumbuhan sumber pangan yang paling banyak adalah yang dibudidayakan karena dengan cara budidaya mempermudah 
dalam mencari tumbuhan tersebut. Keberadaan tumbuhan jenis-jenis tumbuhan sumber pangan terdapat beberapa jenis tumbuhan yang sulit ditemukan didaerah tersebut sebanyak 5 jenis yaitu Asam sadak (Mangifera foetida L.), Asam kandis (Garcinia bancana), Gerambang (Sonneratia caseolaris), Keluntan (Artocarpus sp), Ulap (Baccaurea motleyana).

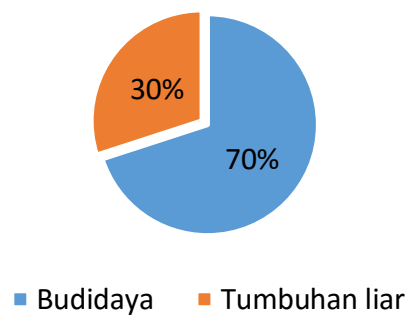

Gambar 6. Status Tumbuhan Sumber Pangan (Status of food source plants)

Berdasarkan hasil penelitian

Nurchayati dan Ardiansyah, (2019)

Suku Using Banyuwangi memanfaatkan tanaman pangan yang berasal dari luar daerah dan hasil budidaya di halaman, pekarangan, kebun maupun areal persawahan. Cara perolehan tanaman dengan cara mendatangkan dari luar daerah biasanya diperoleh dari pasar. Cara tersebut dilakukan ketika halaman, pekarangan, kebun maupun areal persawahan tidak dijumpai tanaman budidaya yang dimaksud. Masyarakat mempermudahkan dalam pencarian jenis tumbuhan dengan cara membudidayakannya.
2. Kelompok Pemanfaatan Tumbuhan Sumber Pangan

Kelompok tumbuhan sumber pangan terdiri dari kelompok buahbuahan terdapat 34 spesies (59\%), kelompok sayur-sayuran sebanyak $21 \%$ (12 spesies), kelompok umbi-umbian 2 spesies (4\%), kelompok rempahrempahan $14 \%$ (5 spesies), kelompok tebu-tebuan $2 \% \quad(1 \quad$ spesies $)$ dan kelompok sereal 2\% (1 spesies). Pemanfaatan yang paling banyak berasal dari kelompok buah-buahan dan yang terendah kelompok sereal dan kelompok tebu-tebuan.

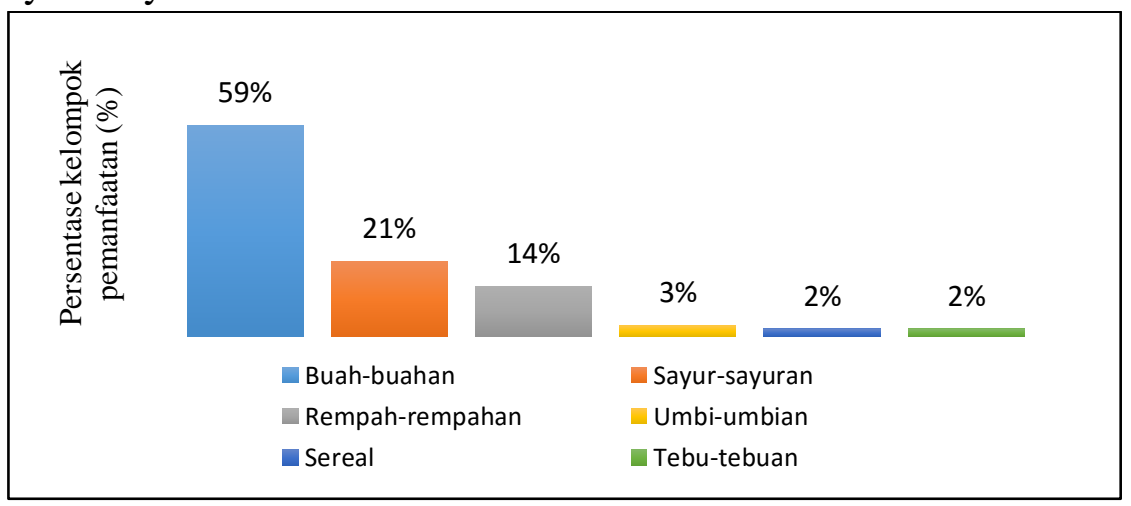

Gambar 7. Kelompok Pemanfaatan Tumbuhan Sumber Pangan (Food source plant utilization group) 
Berdasarkan hasil penelitian Romana et al. (2018) di Dusun Petai Bejambu Desa senakin Kecamatan Sengah Temila Kabupaten Landak ditemukan tumbuhan sumber pangan sebanyak 36 jenis yang terdari dari 24 jenis buah-buahan, 9 jenis sayursayuran, dan 2 jenis umbi-umbian.

\section{Kesimpulan}

1. Jenis tumbuhan sumber pangan yang dimnfaatkan oleh masyarakat Desa Jawai Laut Kecamatan Sambas Kabupaten Sambas yaitu sebanyak 58 spesies dan termasuk 30 famili.

2. Famili yang paling banyak dimanfaatkan adalah famili Aracaceae, Moraceae, Solanaceae masing-masing 4 spesies.

3. Bagian yang paling banyak digunakan oleh masyarakat adalah bagian buah sebanyak 40 spesies (56\%), daun 12 spesies (17\%), bunga 3 spesies (4\%), biji 5 spesies (7\%) dan yang paling sedikit adalah tunas muda, umbi, umbut, kulit, akar.

4. Cara pengolahan tumbuhan sumber pangan yaitu dengan cara dikonsumsi langsung yaitu sebanyak 28 spesies (41\%), dimasak yaitu 35 spesies (51\%), dipermentasikan yaitu 3 spesies (4\%), dihaluskan 3 spesies $(4 \%)$.

5. Tumbuhan yang dimanfaatkan sebagai pangan yaitu sebagai sayuran, bumbu masakan, bahan minuman, dan makanan ringan.

\section{Saran}

Perlu dilakukan upaya program pengembangan pemanfaatan tumbuhan sumber pangan yang berguna oleh masyarakat Desa Jawai Laut Kecamatan Jawai Selatan Kabupaten Sambas yang dapat meningkatkan nilai ekonomis pada tumbuhan tersebut.

\section{DAFTAR PUSTAKA}

Irsyad MN, Jumari, Murningsih. 2013. Studi Etnobotani Masyarakat Desa Sukolilo Kawasan Pegunungan Kendeng Pati Jawa Tengah. Bioma. 15(1): 27-34.

Juliana, Riza L. dan Mukarlin. 2013. Pemanfaatan Tumbuhan Yang Berpotensi Sebagai Sumber Pangan di Gunung Peremas Desa Pangkalan Buton Kecamatan Sukadan Kabupaten Kayong Utara. Protobiont. 2(3): 117-121.

Mulyana D. 2011. Ekonomi Pekarangan Di Pedesaan Jawa. Komunitas. 3(1):19-28

Nurhidayah Y, Lovadi I, dan Linda R. 2015. Tumbuhan Berpotensi Bahan Pangan di Desa Sebangun Kecamatan Sebawi Kabupaten Sambas. Protobiont. 4(1): 151159.

Nurchayati N, Ardiyansyah F. 2019. Pengetahuan Lokal Tanaman Pangan dan Pemanfaatannya pada Masyarakat Suku Using Kabupaten Banyuwangi. Biotropika: Trofical Biology. 07(1): 11-20.

Prabaningrum H, Nugroho AS, Kaswinarni F. 2018. Keanekaragaman Tumbuhan Yang Berpotensi Sebagai Bahan Pangan Di Cagar Alam Gebugan Semarang. Biologi dan Pembelajarannya. 5(2): 26-31.

Setiawan H, Qiptiyah M, 2014. Kajian Etnobotani Masyarakat Adat Suku Moronene Di Taman Nasional 
Rawa Aopa Watumohai. Penelitian Kehutanan Wallacea. 3(2): 107-117.

Sisilahi M, Nisyawati, Anggraeni R. 2018. Studi Etnobotani Tumbuhan Pangan yang Tidak Dibudidayakan Oleh Masyarakat Lokal Sub-Etnis Batak Toba di Desa Peadungdung Sumatera Utara Indonesia. Jurnal Pengelolaan Sumberdaya Alam dan Lingkungan. Vol. 8 No. 2: 241-250.

Sumarlin D, Dirhamsyah M, Ardian H. 2015. Identifikasi Tumbuhan Sumber Pangan di Hutan Tembawang Desa Aur Sampuk Kecamatan Sengah Temila
Kabupaten Landak. Jurnal Hutan Lestari. Vo. 4(1): 32-39.

Sunarti S, Ruqayah, Djarwaningsih T. 2007. Tumbuhan Berpotensi Bahan Pangan di Daerah Cagar Alam Tangale. Biodiversitas. 8(2): 88-91.

Sugiyono. 2016. Metode Penelitian Kuantitatif, Kualitatif dan $R \& D$. Bandung: PT. Alfabet

Romana, Burhanuddin, Thamrin E. 2018. Tumbuhan Sumber Pangan yang Dikonsumsi Oleh Masyarakat Pada Tembawang Pak Kuning Disengah Temila. Jurnal Hutan Lestari. 6(4): 869-874. 